\title{
EFEKTIFITAS KOMUNIKASI INFORMASI DAN EDUKASI (KIE) TENTANG KESEHATAN REPRODUKSI PADA CALON PENGANTIN ( CATIN ) DALAM MEMPERSIAPKAN PERNIKAHAN DAN KEHAMILAN
}

\author{
Meda Yuliani', Iceu Mulyati, ${ }^{2}$ Mamay Maesaroh $^{3}$ \\ 1,2,3 Program Studi D3 Kebidanan, Fakultas IImu Kesehatan, Universitas Bhakti Kencana
}

Email :meda.yuliani@bku.ac.id, iceu.mulyati@bku.ac.id, mamaymaesaroh67@gmail.com

\begin{abstract}
ABSTRAK
Bagi pasangan yang menikah dibawah usia reproduksi dianjurkan untuk menunda kehamilan sampai fisik dan mentalnya siap menerima kehamilannya. Tujuan : mengetahui efektifitas pemberian komunikasi, jnformasi dan edukasi (KIE) tentang kesehatan reproduksi pada calon pengantin. Metode : dalam penelitian ini menggunakan deskriptif kuantitatif. Menggunakan rancangan penelitian cross sectional dan uji wilxocon signed rank test. Dengan tahap pengambilan data primer melaului pre test dan post test menggunakan kuesioner. Sampel dalam penelitian ini adalah pasangan calon pengantin yang berada di wilayah KUA Cileunyi Kabupaten Bandung. Teknik pengambilan sampel menggunakan accidental sampling, dengan jumlah sampel sebanyak 43 pasang calon pengantin. Hasil : menunjukan bahwa ada kenaikan tingkat penhetahuan tentang kesehatan repoduksi pada pasangan calon pengantin setelah dilakukan pemberian komunikasi, informasi dan edukasi (KIE), Hasil dari perhitungan menggunakan rumus Wilcoxon signet rank tes, sebelum dan sesudah menunjukan perbedaan yang signifikan dengan rata - rata sebelum 1,1512 dan sesudah menunjukan nilai rata-rata 1,0000, Hasil uji statistik didapatkan nilai $p$-value $0,000<$ dari nilai alpha (0.05). Kesimpulan : Seluruh responden memiliki pengetahuan baik setelah dilakukan pemberian Komunikasi, Informasi dan edukasi (KIE) pada pasangan calon pengantin. Kemudian bahwa pemberian KIE tersebut efektif dalam peningkatan pengetahuan kesehatan reproduksi dalam upaya persiapan pernikahan dan kehamilan pada pasangan calon pengantin.
\end{abstract}

Kata Kunci : Calon Pengantin, Kesehatan Reproduksi, KIE

\section{PENDAHULUAN}

Perkawinan dimaksudkan untuk membina hubungan yang langgeng antara kedua pasangan, sehingga dalam menjalani perkawinan dibutuhkan kedewasaan dan tanggung jawab baik secara fisik maupun mental. Oleh karena itu, peraturan undangundang mengatur batasan umur pernikahan. ${ }^{5}$ Perkawinan hanya diizinkan bila kedua belah

\section{*Corresponding Author :}

Meda Yuliani

Program Studi D-III Kebidanan Fakultas IImu Kesehatan

University Bhakti Kencana Bandung, Indonesia

Email : meda.yuliani@bku.ac.id pihak pria dan wanita telah mencapai umur 19 (sembilan belas) tahun. ${ }^{5}$ Sedangkan dari segi kesehatan menurut BKKBN (Badan Kependudukan dan Keluarga Berencana Nasional) mengkampanyekan batasan usia yang ideal untuk menikah baik dari segi fisik dan mental, yaitu minimal 21 tahun bagi wanita dan 25 tahun pada pria. ${ }^{1}$ 
Berdasarkan data dari Badan Kependudukan dan Keluarga Berencana Nasional (BKKBN) Jawa Barat rata-rata usia perkawinan pertama perempuan sekarang mencapai 19,8 tahun. Usia perempuan ini biasanya menjadi indikator perkawinan dini atau bukan. Indikatornya dari usia perkawinan pertama perempuan. ${ }^{9}$ Kesiapan dalam pernikahan salah satunya adalah secara fisik siap untuk menghadapi proses kehamilan. Program keluarga berencana merupakan salah satu cara untuk menunda kehamilan yang salah satu fungsinya untuk mempersiapkan reproduksi sehat. Bagi pasangan yang menikah dibawah usia reproduksi dianjurkan untuk menunda kehamilan sampai kesipan fisik dan mentalnya siap menerima kehamilannya. Pernikahan dan kehamilan yang terjadi kurang dari usia 20 tahun beresiko, resiko yang bisa terjadi adalah anemia pada kehamilan, bayi lahir premature atau pun berat badan lahir rendah, persalinan dengan resiko perdarahan., ${ }^{3,2}$ Pemberian informasi mengenai kehamilan tersebut bisa dilakukan pada kelas catin mengenai kesehatan reproduksi salah satunya tentang penggunaan alat kotrasepsi sebagai penunda kehamilan untuk mengurangi angka kesakitan dan angka kematian ibu dan bayi. Tujuan dari penelitian ini untuk mendapatkan gambaran pengetahuan pasa pasangan calon pengantin Pria dan Wanita sebelum dan sesudah pemberian komunikasi, informasi dan edukasi (KIE), serta untuk mengetahui efektifitas pemberian dari pemberian KIE tersebut.

\section{METODE}

\section{Rancangan Penelitian}

Jenis penelitian yang digunakan adalah deskriptif kuantitatif dengan rancangan cross sectional. Desain ini digunakan untuk menggambarkan pengetahuan tentang kesehatan reproduksi pada calon pengantin dan keefektifan pemberian Komunikasi, Informasi dan Edukasi (KIE) terhadap pengetahuan Calon pengantin.

\section{Populasi dan Sampel}

Populasi dan sampel dalam penelitian ini merupakan pasangan calon pengantin yang berada di wilayah KUA Cileunyi Kabupaten Bandung. Teknik pengambilan sampel menggunakan Accidental sampling yang mana sampel yang diambil adalah pasangan calon pengantin yang datang ke KUA Cileunyi pada saat kegiatan Bimbingan Perkawinan (Bimwim). Jumlah Sampel yang diperoleh sebanyak 43 pasang calon pengantin yang datang ke KUA bersama dengan pasangannya, dan calon pasangan pengantij yang akan menikah untuk pertama kalinya ataupun tidak.

\section{Teknik Pengumpulan Data}

Data diperoleh dengan data primer yaitu membagikan kuesioner kepada responden dengan dilakukan Prosedur pre test dan post test kepada calon pengantin mengenai pengetahuan kesehatan reproduksi dalam persiapan pernikahan dan kehamilan. Setelah itu kemudian dianalisis sebelum dan sesudah pemberian komunikasi, Informasi dan edukasi (KIE).

\section{Analisis Data}

Data dianalisis menggunakan analisis univariat untuk mengetahui tingkat pengetahuan calon pengantin wanita dan pria sebelum dan sesudah pemberian KIE. Dalam analisa ini hanya menghasilkan distribusi frekuensi dan persentase. Analisis selanjutnya yaitu analisa bivariat di lakukan terhadap variabel dengan menguji efektivitas pemberian edukasi tentang kesehatan reproduksi pada pasangan calon pengantin dengan menggunakan bantuan software SPSS 16. . Sebelum dilakukan uji statistik terlebih dahulu dilakukan pengujian normalitas data dengan menggunakan Shapiro-Wilk baik pada data sebelum maupun sesudah tindakan. Berdasarkan hasil perhitungan Shapiro-Wilk pada data sebelum pemberian KIE didapatkan hasil 0,000 sedangkan pada data sesudah pemberian KIE adalah 0,000. Dari hasil hitung baik sebelum dan sesudah pemberian KIE kurang dari 0,005 maka distribusi data tersebut dinyatakan distribusi tidak normal.

\author{
*Corresponding Author : \\ Meda Yuliani \\ Program Studi D-III Kebidanan Fakultas IImu Kesehatan \\ University Bhakti Kencana Bandung, Indonesia \\ Email : meda.yuliani@bku.ac.id
}


Dikarenakan hasil uji normalitas data hasilnya tiak berdistribusi normal, maka menggunakan uji nonparametris dengan menggunakan wilcoxon signed rank tes. edukasi seluruh responden berpengetahuan baik $100 \%$.

\section{HASIL DAN PEMBAHAS AN}

Hasil Analisa Univariat

Tabel 1.

Distribusi Frekuensi Tingkat Pengetahuan Pada Calon Pengantin (Catin) Wanita sebelum dan sesudah Pemberian KI

\begin{tabular}{lllll}
\hline Tingkat & \multicolumn{2}{l}{ Sebelum } & \multicolumn{2}{l}{ Sesudah Edukasi } \\
pegetahuan & \multicolumn{2}{l}{ Edukasi } & & \\
\cline { 3 - 5 } & $\mathrm{F}$ & $\%$ & $\mathrm{~F}$ & $\%$ \\
\hline Baik & 37 & 86.0 & 43 & 100.00 \\
Cukup & 6 & 14.0 & & \\
\hline Total & 43 & 100.0 & 43 & 100.00 \\
\hline
\end{tabular}

Berdasarkan Tabel 1 menunjukan hasil analisis univariat tentang pengetahuan pada calon pengantin wanita sebelum dan sesudah pemberian KIE. Didapatkan hasil bahwa sebelum edukasi Sebagian besar berpengetahuan baik 86.0 dan sesudah edukasi seluruh responden berpengetahuan baik $100 \%$.

Tabel 2.Distribusi Frekuensi Tingkat Pengetahuan Pada Calon Pengantin (Cantin) Pria sebelum dan sesudah Pemberian KIE

\begin{tabular}{lllll}
\hline Tingkat & \multicolumn{2}{l}{ Sebelum Edukasi } & \multicolumn{2}{l}{ Sesudah Edukasi } \\
\cline { 4 - 5 } pegetahuan & $\mathrm{F}$ & $\%$ & $\mathrm{~F}$ & $\%$ \\
\hline Baik & 36 & 83,7 & 43 & 100,0 \\
Cukup & 7 & 7.0 & & \\
\hline Total & 43 & 100.0 & 43 & 100.0 \\
\hline
\end{tabular}

Berdasarkan Tabel 2 tentang pengetahuan pada calon pengantin pria sebelum dan sesudah pemberian edukasi menunjukan bahwa sebelum edukasi Sebagian besar berpengetahuan baik $83.7 \%$ dan sesudah
Tabel 3 Distribusi Frekuensi Tentang kebermanfaatan Komunikasi, Informasi dan Edukasi (KIE) Tentang Kesehatan Reproduksi Bagi Pasangan Calon Pengantin (Catin)

\begin{tabular}{llc}
\hline Kebermanfaatan KIE & \multicolumn{2}{l}{ Sebelum Edukasi } \\
& $\mathrm{F}$ & $\%$ \\
\hline $\begin{array}{l}\text { Perlu / bermanfaat } \\
\text { Tidak perlu / tidak }\end{array}$ & 43 & 100 \\
$\begin{array}{l}\text { Bermanfaat } \\
\text { Total }\end{array}$ & 0 & 0 \\
\hline
\end{tabular}

Berdasarkan tabel 3 hasil analisis mengenai kebermanfaatan tentang pemberian komunikasi, informasi dan edkuasi (KIE) tentang kesehatan reproduksi pada pasangan calon pengantin (Catin), selurh responden pasangan calon pengantin beranggapan bahwa sangat bermanfaat / diperlukan untuk para pasangan calon pengantin untuk mempersiapkan kesehatan reproduksinya.

\section{Hasil Analisa Bivariat}

Tabel 4. Efektifitas Pemberian Edukasi Tentang Kesehatan Reproduksi Pada Pasangan Calon Pengantin

\begin{tabular}{l|l|ll}
\hline Perlakuan & Mean & $\begin{array}{l}\text { Std. } \\
\text { Deviation }\end{array}$ & $\begin{array}{l}\text { P- } \\
\text { value }\end{array}$ \\
\hline Pre tes & 1.1512 & 0.36031 & \\
Post tes & 1.0000 & 0.00000 & 0.000 \\
\hline
\end{tabular}

\author{
*Corresponding Author : \\ Meda Yuliani \\ Program Studi D-III Kebidanan Fakultas IImu Kesehatan \\ University Bhakti Kencana Bandung, Indonesia \\ Email : meda.yuliani@bku.ac.id
}


Analisa bivariat dilakukan terhadap variabel dengan menguji efektivitas pemberian edukasi tentang kespro pada catin wanita dan, dengan menggunakan bantuan software SPSS 16. Sebelum dilakukan uji statistik terlebih dahulu dilakukan pengujian normalitas data dengan menggunakan Shapiro-Wilk baik pada data sebelum maupun sesudah tindakan. Berdasarkan hasil perhitungan Shapiro-Wilk pada data sebelum didapatkan 0,000 sedangkan pada data sesudah adalah 0,000 karena nilai ShapiroWilk hitung baik sebelum dan sesudah tindakan kurang dari 0,005 maka distribusi data sebelum dan sesudah pemberian edukasi tersebut dinyatakan distribusi tidak normal, sehingga menggunakan uji nonparametris dengan menggunakan wilcoxon signet rank tes

Hasil pengolahan data didapatkan bahwa rata-rata sebelum edukasi dan sesudah edukasi hasil dari perhitungan dengan menggunakan rumus wilcoxon signed rank tes sebelum dan sesudah menunjukan perbedaan yang signifikan dengan rata - rata sebelum 1.1512 dan sesudah menunjukan nilai rata-rata 1.0000 , Hasil uji statistik didapatkan nilai $p$-value $0,000<$ dari nilai alpha (0.05) dapat disimpulkan efektif antara sebelum dilakukan pemberian edukasi dengan sesudah dilakukan pemberian edukasi sehingga $\mathrm{H}_{0}$ di tolak dan $\mathrm{H}_{\mathrm{a}}$ diterima

\subsection{Pembahasan}

Tingkat pengetahuan calon pengantin sebelum dilakukan penyuluhuan berdasarkan hasil penelitian pada tingkatan Sebagian besar 37 responden calon pengantin perempuan berpengetahuan baik dan 36 repsonden calon pengantin pria berpengetahuan baik. Pengetahuan yang baik ini didukung dengan mendapatkan informasi dari media elektronik yang sekarang ini mudah sekali diakses. Selain itu pendidikan responden yang Sebagian besar berpendidikan SMA juga turut mempengaruhi terhadap pengetahuan baik responden tentang kesehatan reproduksi.

Hasil penelitian yang dilakukan di Malawi, di dapatkan bahwa remaja wanita memerlukan pengetahuan tentang kesehatan reproduksi. Untuk kesiapaan jika hamil muda, melhiarkan muda, kesalahpahaman tentang kontrasepsi. Karena kondisinya didaerah sana memang angka kehamilan remajanya tinggi. Dan itu salah satunya karena ketidaktahuan tentang kesehetan reproduksi. ${ }^{20}$

Penelitian sebelumnya yang dilakukan bahwa sebagian besar calon pengantin di KUA Umbulharjo Yogyakarta memiliki pengetahuan baik tentang kesehatan reproduksi. Pengetahuan yang baik diperoleh calon pengantin dari sumber pengetahuan, seperti : media massa (cetak dan elektronik, buku-buku dan majalah kesehatan. Disamping itu pendidikan responden yang Sebagian besar SMA juga turut mempengaruhi pengetahuan tentang kesehatan reproduksi. ${ }^{13}$

Tingkat pengetahuan calon pengantin pria dan calon pengantin wanita memiliki tingkat pengetahuan yang Sebagian besar berpengetahuan baik pada sebelum pemberian edukasi. Dan setelah pemberian edukasi tingkat pengetahuan repsonden seluruh responden memiliki tingkat pengetahuan baik.

Penelitian yang dilakukan terhadap calon pengantin di Lubuk Begalung Kota Padang menunjukkan hal yang sama dengan penelitian ini dimana dari $31,6 \%$ responden dengan pengetahuan rendah sebelum konseling pranikah diberikan menjadi $97,4 \%$

\footnotetext{
*Corresponding Author :

Meda Yuliani

Program Studi D-III Kebidanan Fakultas Ilmu Kesehatan

University Bhakti Kencana Bandung, Indonesia

Email : meda.yuliani@bku.ac.id
} 
dengan pengetahuan tinggi setelah dilakukan konseling. ${ }^{10}$

Dalam peneliitian ini menunjukan bahwa seluruh repsonden calon pengantin pria ataupun wanita memiliki pengetahuan baik. Dalam pemberian edukasi ini memberikan tambahan peningkatan pengetahuan khusunya kepada calon pengantin pria yang biasanya terkadang sulit untuk dilibatkan dalam hal kesehatan reproduksi. Hal ini seperti yang dikemukanan dalam sebuah penelitian, bahwa keterlibatan laki-laki dalam hal kesehatan reproduksi itu sulit, sehingga diperlukan untuk pemberian edukasi dengan melibatkan remaja laki-laki juga sebagai persiapn dalam kehidupan kesehatan reproduksi. ${ }^{18}$

Temuan dari studi yang di lakukan di pengusian kobe Somalia, menginformasikan program masa depan di Kobe dan dengan fokus pada kebutuhan kesehatan dan pembangunan kesehatan remaja. Program masa depan harus mempertimbangkan determinan dari kesehatan dan pembangunan remaja, termasuk akses ke pendidikan, gender keadilan, dan keamanan.dengan kata lain pendidikan diperlukan untuk pembangunan kesehatan remaja, baik berupa pemberian edukasi,ataupun pendidikan formal lainnya. 15

Pendidikan kesehatan reproduksi dan seksual diperlukan sebagai pendukung sumber daya masa depan dalam kesehatan seksual yang bukan hanya seksual aman dan kontrasepsi saja. Tetapi sebagai penyedia untuk meningkatkan kesehatan reproduksi. ${ }^{17}$

Setiap pasangan yang akan menikah harus memiliki pengetahuan yang cukup baik mengenai sistem reproduksi yang termasuk di dalamnya manfaat metode kontrasepsi, penggunaan alat kontrasepsi yang cocok di masa awal pernikahan jika belum menginginkan kehamilan, dan masalah kesehatan reproduksi lainnya. WHO menyatakan bahwa. pendidikan seksual Whebtukitananpagi orang yang berada pada

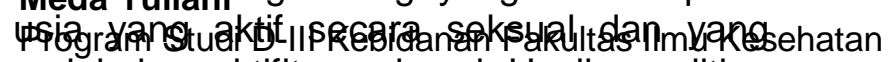

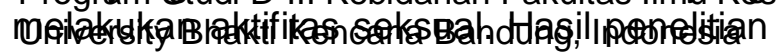

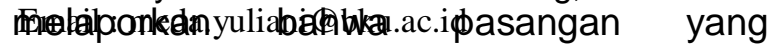

mendapatkan konseling pranikah dapat menurunkan peluang terjadinya perceraian sebanyak $31 \% .{ }^{11}$

Pembuat kebijakan dan praktisi melaporkan bahwa keterlibatan pria yang lebih besar pada kesehatan reproduksi akan menghasilkan berbagai manfaat untuk kesehatan ibu dan anak, terutama melalui akses yang lebih besar ke layanan dan intervensi untuk perempuan dan anak-anak. 16

Peran pasangan dalam hal mempersiapkan kehamilan dan persalinan diperlukan sebagai suatu kondisi untuk berbagi peran saat nantinya. ${ }^{22}$

Maka dalam hal ini diperlukan pengethaun kepada psangan terutama calon pengantin pria untuk mempersiapkan masa kehamilan dan melahirkan untuk pasangannya.

Pada penelitian di Ghana tahun 2017, didaptkan hasil bahawa Sekitar 35\%, 44\%, dan $20 \%$ pria menemani pasangannya perawatan antenatal, persalinan, dan perawatan postnatal, masing-masing. Keterlibatan pria dalam asuhan antenatal dan persalinan dipengaruhi oleh sosiodemografi, salah satunya adalah pendidikan dan pengetahuan. ${ }^{24}$

Dari hasil penelitian bahwa semua responden beranggapan bahwa adanya pemberian komunikasi, informasi dan edukasi mengenai kesehatan reproduksi sangat perlu ataupun bermanfaat, karena bisa memberikan peningkatan pengetahuan dan gambaran mengenai kesehtan repoduksi dan persiapan pernikahan dan juga dalam mempersiapkan kehamilan pada nantinya baik untuk calon pengantin wanita ataupun kepada calon pengantin pria sebagai pendamping.

Pada studi inipun Pemberian komunikasi, informasi dan edukasi (KIE ) secara hasil uji efektifitas dengan menggunakan pengujian wilxocon signed rank test menunjukan bahwa rata-rata sebelum edukasi dan seudah edukasi hasil dari perhitungan dengan menggunakan rumus Wilcoxon Signed Rank Tes sebelum dan sesudah menunjukan perbedaan yang signifikan dengan rata - rata sebelum 1.1512 dan sesudah menunjukan 
nilai rata-rata 1.0000 , Hasil uji statistik didapatkan nilai $p$-value $0,000<$ dari nilai alpha (0.05) dapat disimpulkan efektif antara sebelum dilakukan pemberian edukasi dengan sesudah dilakukan pemberian edukasi.

Penelitian yang dilakukan sebelumnya di KUA kota Padang, diketahui lebih dari separuh responden $(79,6 \%)$ memiliki tingkat pengetahuan tinggi tentang kesehatan reproduksi setelah diberikan konseling pra nikah. ${ }^{12}$

Status kesehatan ibu sebelum kehamilan merupakan faktor penentu untuk proses dan hasil dari kehamilan serta risiko untuk komplikasi ibu dan bayi. Dalam masyarakat Barat perawatan prakonsepsi (PCC) secara luas dikenal sebagai cara untuk mengoptimalkan kesehatan wanita melalui perubahan biomedis dan perilaku sebelum pembuahan tujuan meningkatkan hasil kehamilan. ${ }^{16}$

Pendidikan kesehatan yang dilakukan di didalam program bimbingan perkawinan ini bisa sebagai pusat informasi kesehatan reproduksi bagi calon pengantin. ${ }^{8}$ Pemberian edukasi kesehatan reproduksi yang dilakukan ini menunjukan hasil efektif untuk meningktkan pengetahuan responden mengenai kesehatan reproduksi, dalam persiapan kehamilan untuk lebih bisa menjaga dan mempersiapkan kesehatan pada saat hamil. Penelitian yang dilakukan di India, bahwa pusat informasi kesehatan remaja dapat menurunkan angka pernikahan dini dan bisa meningkatkan angka rentensi kelulusan sekolah pada remaja. Hal ini menunjukan bahwa dengan diberikan pengetahuan dapat memberikan dan meningkatkan kesehatan reproduksi. ${ }^{21}$

Pendidikan kesehatan reproduksi ini berupa konseling pemberian informasi dan edukasi tentang penundaan kehamilan yang sehat, kondisi gender dalam persiapan pernikahan dan materi tentang kesehatan reproduksi lainnya yang dapat menunjang kebutuhan kesehatan reproduksi calon pengantin.

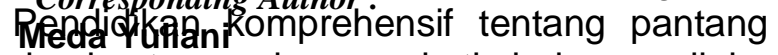

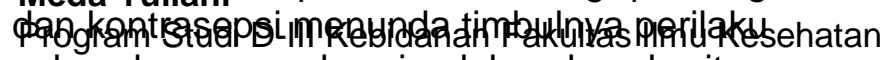

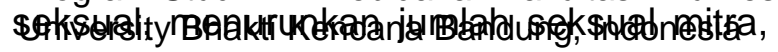
Email : meda.yuliani@bku.ac.id dan meningkatkan penggunaan kontrasepsi. 7,23

pendidikan ini bisa dilakukan tidak pada saat akan menikah saja, hal ini bisa dilakukan pada saat persipan menuju dewasa, remaja. Seperti Pendidikan kesehatan reproduksi ini bisa dilakukan dila tempat pelayanan seperti pediatri (dokter anak) yang untuk mempersiapkan remaja menuju dewasa, pendampingan pada orang tua nya juga. ${ }^{4,19}$

\section{KESIMPULAN DAN SARAN}

Pengetahuan responden sebelum dan sesudah pemberian komunikasi, informasi dan edukasi (KIE) baik pada calon pengantin wanita dan calon pengantin pria mengalami peningkatan, dimana hasilnya seluruh reponden memiliki pengetahuan baik. serta dari hasil uji perbedaan terdapat rerata perbedaan antara sebelum dan sesudah pemberian KIE,dan dapat disimpulkan bahwa sebelum dan sesudah pemberian KIE tentang kesehatan reproduksi tersebut efektif dalam upaya peningkatan pengetahuan kesehatan reproduksi dalam mempersiapkan pernikahan dan kehamilan.

Diharapkan kepada KUA setempat untuk menjadikan materi kesehatan reproduksi menjadi materi wajib yang harus disampaikan kepada calon pengantin dan bisa melakukan revitalisasi kembali Kerjasama dengan pihak terkait untuk perihal penyuluhan materi kesehatan.

\section{DAFTAR PUSTAKA}

1. Sulistyawati . 2019. Pelayanan Keluarga Berencana. Jakarta: Salemba Medika

2. Kementerian Kesehatan Republik Indonesia. 2014 Tentang Pedoman Manajemen Keluarga

Berencana. Jakarta : Kemenkes RI

3. Kementerian Kesehatan RI. 2014. Kesehatan Reproduksi dan Seksual Calon Pengnatin. Jakarta : Kemenkes RI 
4. Arik V MarcellSexual and Reproductive Health Care Services in the Pediatric Setting. Pediatrics. 2017; 140(5): e20172858

5. Undang-Undang Republik Indonesia. 1974. Tentang Perkawinan. Jakarta : Yayasan Peduli Anak

6. Undang-Undang Republik Indonesia. 2019. Undang -Undang No. 16 Tahun 2019 Tentang Revisi Undang-Undang Perkawinan tahun 1974. Jakarta

7. Riantini Amelia. 2018. Efektifitas Penyuluhan Kesehatan Reproduksi Pada Calon Pengantin Di Puskemas pringsewu Surabaya.

8. Atik J. 2020. Pengaruh penyuluhan Kesehatan Reproduksi Terhadap Tingkat Pengetahuan calon Penganti. http://journal.aisyahuniversity.ac.id/index. php/Jaman/article/view/119

9. BKKBN terdapat pada.

https://www.bkkbn.go.id/detailpost/nikahmuda di lihat 18 feb 2020

10. Susanti D, Rustam Y, Doni AW. Pengaruh Pendidikan Kesehatan Pranikah terhadap Pengetahuan dan Sikap Calon Pengantin di Lubuk Begalung Padang. Jurnal Sehat Mandiri. 2018;13(2):18-25

11. Mahmoodi G. The effect of marriage counseling on the knowledge of the married couples. Int $\mathrm{J}$ Med Res Health

Sci. 2016;5(7S):354-35

MedGarponding Author :Efektifitas Konseling Progk

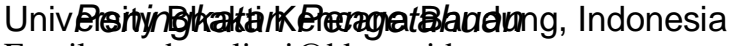
Email : meda.yuliani@ bku.ac.id
Kesehatan Reproduksi Pasangan Calon Pengantin di KUA Kota Padang

13. Rizka H, 2016. Hubungan Tingkat Pengetahuan Tentang Kesehatan Reproduksi Dengan Kesiapan Menikah Pada Calon Pengantin Di Kua Umbulharjo Yogyakarta Tahun 2016

14. Anwar h, 2014. Tutorial Cara Uji Wilcoxon Signed Rank Test. Terdapat pada : https://www.statistikian.com/2014/07/tuto rial-uji-wilcoxon-signed-rank-test.html

15. Meghan Greeley, Understanding the unique experiences, perspectives and sexual and reproductive health needs of very young adolescents:Somali refugees in Ethiopia. Conflict and Health 2017, 11(Suppl 1):26 DOI 10.1186/s13031017-0129-6

16. Jessica Davis, Male involvement in reproductive, maternal and child health: a qualitative study of policymaker and practitioner perspectives in the PacificReproductive Health (2016) 13:81 DOI 10.1186/s12978-016-0184-2

17. Natasha N. Frederick et,al. Barriers and facilitators to sexual and reproductive health communication between pediatric oncology clinicians and adolescent and young adult patients: The clinician perspective. 2018. wileyonlinelibrary.com/journal/pbc. https://doi.org/10.1002/pbc.27087

18. Sara Bylund, Mats Målqvist, Nosim Peter \& Sibylle Herzig van Wees (2020) Negotiating social norms, the legacy of vertical health initiatives and contradicting health policies: aqualitative study of health professionals' perceptions and attitudes of providing adolescent sexualand reproductive health care in Arusha and Kilimanjaro region, Tanzania, Global Health Action,13:1, 1775992, DOI: 10.1080/16549716.2020. 
19. Kristin Nash, Gabrielle O'Malley, Elizabeth Geoffroy, Ellen Schell, Alice Bvumbwe4 and Donna M. Denno. "Our girls need to see a path to the future"-perspectives on sexual and reproductive health information among adolescent girls, guardians, and initiation counselors in Mulanje district, Malawi. Nash et al. Reproductive Health (2019) 16:8. https://doi.org/10.1186/s12978-0180661-x

20. Devika Mehra, Archana Sarkar, Priyanka Sreenath, Jagannath Behera and Sunil Mehra. Effectiveness of a community based intervention to delay early marriage, early pregnancy and improve school retention among adolescents in India. Mehra et al. BMC Public Health (2018)

18:732. https://doi.org/10.1186/s12889-0185586-3

21. Erfanian Arghavanian F, Heydari A, Noghani Dokht Bahmani M, Latifnejad
Roudsari R. An Account of Iranian Pregnant Women' Experiences of Spousal Role: An Ethnophenomenological Exploration. Journal of Midwifery and Reproductive Health. 2020; 8(4): 2404-2418. DOI: 10.22038/jmrh.2020.49044.1606

22. Burke PJ, Coles MS, Di Meglio G, et al;Society for Adolescent Health and Medicine. Sexual and reproductive health care: a position paper of the Society for Adolescent Health and Medicine. J Adolesc Health. 2014;54(4):491-496

23. Joshua Panyin Craymah, Robert Kwame Oppong, and Derek Anamaale Tuoyire. Male Involvement in Maternal Health Care at Anomabo,Central Region, Ghana. International Journal of Reproductive Medicine Volume 2017, Article ID 2929013, 8 pages. https://doi.org/10.1155/2017/2929013

\footnotetext{
*Corresponding Author : Meda Yuliani

Program Studi D-III Kebidanan Fakultas IImu Kesehatan University Bhakti Kencana Bandung, Indonesia Email : meda.yuliani@bku.ac.id
} 